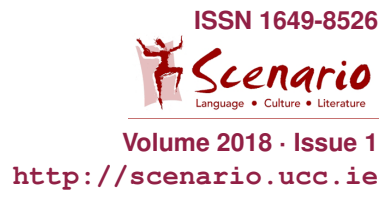

Review

\title{
Ní Shíocháin, Tríona (2018). Singing Ideas: Performance, Politics and Oral Poetry. New York and Oxford: Berghahn
}

\section{Erika Piazzoli}

Singing Ideas: Performance, Politics and Oral Poetry is a fascinating insight into the Irish tradition of singing and its potency to fuel political thought and identity, in the context of eighteenth-century Ireland. To that purpose, Tríona Ní Shíocháin takes us through an informed analysis of the lived-experience of one historical figure, the magnetic Máire Bhuí Ní Laeire (Yellow Mary O'Leary).

One of the greatest Irish song poets of her time, Máire Bhuí Ní Laeire was born in 1774 and died during the Great Irish Famine in 1848. She is depicted as a charismatic woman who composed and sang anti-colonial ideas, mocking nobility and denouncing social exploitation in Ireland. During her life, her craft gained her the reputation of a prophetic figure, a truth-teller or parrhesiast - a Greek notion that, as Foucault (2011) holds, refers to those with the courage to address urgent political issues, in public, even if running the risk of putting their lives in danger. Parrhesia, Foucault argues, can set social and historical change in motion - and that is precisely what seems to have happened through Máire Bhuí Ní Laeire's subversive singing.

Through the unique lens of this fascinating character, Ní Shíocháin is able to paint a vivid picture of anticolonial Ireland in the eighteenth century. Rather than limiting her work to a historical analysis of the compositions, Ní Shíocháin draws on the many interpretations of Máire Bhuí Ní Laeire's personae. She offers an anthropological account of the popular song poet, focussing on her presence in other singers' compositions, as well as the narrative accounts by her contemporaries. This is contextualised within the historical and political events of the time - yet filtered through Máire Bhuí Ní Laeire's perspective.

What emerges is a colourful account of a fearless woman, who eloped to West Cork with her lover as a youngster, leaving her well-off family behind to become a respected song poet, in a society dominated by male song composers. She sang in Irish, a language that was forbidden under colonial rule. Illiterate, the mother of nine children, she is portrayed through her creations as witty, resilient, brave - a visionary who was highly respected by her community.

As we read on, we come to realise that the repertoire of songs presented in the book are dynamic and multi-vocal: they are Máire Bhuí Ní Laeire's response to the historical events around her, as channelled by the people, inherited by the people, performed by herself and other singers who later diffused her 
compositions. They were multi-vocal, in the sense that they were collectively owned by the wider community.

The author digs deeper than just analysing the lyrics, rhythm, or the melodic structure of her songs: she dwells in the symbolism of the lived-experience of song, a performance coming to life in the act of being performed. The underpinning argument here is that song is more than just text: in a performative key, it is construed as a generative space that incubates ideas, giving life to "ecstatic ludic spaces" (3), breeding the seeds of a current that culminated in the 1916 Easter Rising and the Irish War of Independence.

Ní Shíocháin draws on Turner's (1969) theory of rites of passage and liminality to describe Máire Bhuí Ní Laeire's compositions as generating liminal spaces. For Turner, rites of passage embody change in society, a symbolic 'death' so-to-speak, followed by a new status. The transition between these phases can be seen as a liminal phase, a threshold in which normal social structures are suspended - what he terms, an anti-structure. In Turner's eye, liminality is an in-between state, "betwixt and between the positions assigned and arrayed by law, custom, convention and ceremonial" (ibid. 95). As such, the 'anti-structure of liminality' created by singing satirical pieces can breed endless possibilities, whereby new forms can emerge.

As the chapters progress, we realise how Máire Bhuí Ní Laeire's song poetry created liminal spaces that catalysed a political impulse for action - an impulse which, less than a century later, culminated in the independence of Ireland from the British crown. Ní Shíocháin stresses this point, offering a scholarly analysis of the medium of singing to create communitas - collective lived experiences that ignite a sense of ecstatic trance, affirming and re-creating identity. "The mimesis of song", she argues, "means that song is not just commemorative, but flows into and animates the present moment" (116). She focuses on the anthropology of experience which, with Bruner and Turner (1986), shifts the focus from the observer's point of view, to the experience itself:

The anthropology of experience turns our attention to experience and its expression to indigenous meaning. The advantage of beginning the study of culture through expressions is that the basic units of analysis are established by the people we study, rather than by the anthropologist as alien observer. (Bruner \& Turner 1986: 9)

Ní Shíocháin makes a convincing argument highlighting that, in eighteenthcentury Ireland, singing in Irish was a potent medium, able to reach the masses much more than written English propaganda. While in the Western tradition we may tend to assume that written evidence holds a higher status, in this case song poetry within the oral tradition carries a decisively heavier weight. Sung oral poetry, in Irish, was able to disrupt the dominant discourse much more than the written word, in English. This lead to an ongoing process of identity formation, as the songs "continued to create an ecstatic time outside of time" (Weber 1978: 1119). In that, the author presents Máire Bhuí Ní Laeire as "a singer of ideas" (4), a concept encapsulated in the title of the book. 
Structured into three eloquent chapters and a conclusion, the book features a detailed appendix section containing the Irish compositions, the English translations and the music transcriptions, as well as a list of sound recordings, bibliography and discography. As readers, we are left with a thirsty ear, craving to listen to Máire Bhuí Ní Laeire's musical makings, perhaps hoping to gain an aural glimpse into those "liminal moments of sheer potentiality" (3) that have inspired generations of women, and men, before us.

\section{Bibliography}

Bruner, Edward \& Turner, Victor (eds.) (1986): The Anthropology of Experience. Chicago: University of Illinois Press

Foucault, Michel (2011): The Courage of Truth: Lectures at the Collège de France 1983-1984. Basingstoke: Palgrave Macmillan

Turner, Victor (1969): The Ritual Process - Structure and Anti-Structure. London: Routledge and Kegan Paul

Weber, Max (1978): Economy and Society. Los Angeles: University California Press 